\title{
ERIC PAWSON: AN APPRECIATION OF A NEW ZEALAND CAREER
}

\author{
GRAEME WYNN \\ University of British Columbia
}

After an academic career extending over four decades, Eric Pawson retired in April 2017 as New Zealand's pre-eminent historical geographer, as a leading light among the country's environmental historians, and as a scholar with international recognition in both fields. Recognising these achievements with this special issue of the International Review of Environmental History is entirely appropriate. But limiting my appreciation to these contributions - as the editor's invitation and space allocation compel me to do-is to annotate only a part of Eric's intellectual influence and to risk diminishing a diverse career well spent. The tight focus of what follows should not obscure Eric's significant roles as an intellectual leader among New Zealand geographers, as an important participant in the day-to-day workings of his own university, and above all as an award-winning teacher and frequent contributor to the scholarship of teaching and learning. ${ }^{1}$

Eric Pawson came to the University of Canterbury in February 1976. Twentyfour years old, he had recently completed an Oxford DPhil thesis on the turnpike roads of eighteenth-century England. It would soon be published as Transport and Economy $(T \& E)$. In Christchurch he joined Peter Perry, another English-trained historical geographer (from the 'other place'), a specialist on English agriculture, whose A Geography of Nineteenth-Century Britain had just appeared. ${ }^{2}$ Following his colleague's lead, Pawson began his New Zealand years looking homeward, and wrote, in longhand and astonishingly quickly, a short book on Britain in the

\footnotetext{
1 Brief accounts of these dimensions of Eric Pawson's career can be found in: 'Distinguished New Zealand Geographer Award 2007', www.nzgs.co.nz/images/stories/nzgs/pdfs/nzgs-citations/ericpawson.pdf and 'Dr Eric Pawson-Tertiary Teaching Excellence Teaching Profile', akoaotearoa.ac.nz/community/ako-aotearoa-academytertiary-teaching-excellence/resources/pages/dr-eric-pawson-tertiary-. The citation accompanying the New Zealand Geographical Society Distinguished Service Award to Eric Pawson in 2010 reads, in part: 'Professor Pawson received the Award for his role as Managing Editor of the New Zealand Geographer, his pre-eminence as a geographical educator and his organisational capabilities, for which New Zealand geography has been a primary beneficiary.'

2 Peter J. Perry, A Geography of Nineteenth Century Britain (London: Batsford, 1975).
} 
eighteenth century with a 1978 copyright date. Both T\&E and The Early Industrial Revolution (EIR) were avowed historical geographies, and products of their timesas well as of the boldness of able youth. ${ }^{3}$

Long neglected, turnpikes became a focus of revisionist interest in the 1970s as Eric and others challenged the oft-repeated disparagement of English roads by dyspeptic eighteenth-century travellers, and the later critical assessment of turnpike trusts by Sidney and Beatrice Webb. Although he drew much evidence from parliamentary records and manuscript sources in county record offices, Pawson sought to address general themes-innovation, diffusion, connectivity and patterns of economic activity-rather than to depict local circumstances. The explicitly methodological preface to $T \& E$ declared Pawson's interest in macrolevel problems rather than sources. Taking leads from 'new' scientific and analytical geography and the 'new economic history', $T \& E$ pursued a theoretical deductive approach; it would, vowed its author, stand apart from so many of its locally focused predecessors that were 'at best of interest to the worthies of Draynflete, at worst to no one', and be of value to 'the rest of the historical fraternity', as well as geographers. ${ }^{4} \mathrm{~A}$ few years later, these efforts were pressed further in an article that generalised the turnpike work and used the dynamic model developed in $T \mho E$ to portray transport developments as deep-seated structural events integral to processes of economic change. ${ }^{5}$

EIR aimed to provide students in historical geography with some of the 'more illuminating and worthwhile [recent] findings', about economic and geographical change during the formative century of Britain's industrialisation. ${ }^{6}$ Intended to be broadly accessible, the book was clearly written and fairly orthodox in its organisation. After a brief introduction to the industrial revolution, eight chapters dealt with such topics as population growth, agricultural expansion, basic industries, internal trade and communication, and urban change. Attention to spatial patterns signified the book's geographical pedigree, although it rested heavily on the work of economic

\footnotetext{
3 The times they were a-changin', and much has been written about them. Pawson notes M. J. Bowden, 'Review: Three Generations of British Historical Geography', Economic Geography, 48 (1972): 214-16, doi.org/10.2307/142878 as a stimulating critique of earlier work; see also Cole Harris, 'Theory and Synthesis in Historical Geography', The Canadian Geographer 15, no. 3 (September 1971): 157-72, doi.org/10.1111/j.1541-0064.1971.tb00154.x, and for one retrospective reflection Graeme Wynn, “Tracing One Warm Line Through a Land So Wide and Savage”: Fifty Years of Historical Geography in Canada', Historical Geography 40 (2012): 5-32.

4 Eric Pawson, Transport and Economy: The Turnpike Roads of Eighteenth Century Britain (London and New York: Academic Press, 1977); for other work on turnpikes see also William Albert, The Turnpike Road System in England, 1663-1840 (Cambridge: Cambridge University Press, 1972) and John Chartres, 'Road Transport and Economic Growth in the 18th Century', Refresh 8 (Spring 1989): 5-8.

5 Eric Pawson, 'Transport and Development: Perspectives from Historical Geography', International Journal of Transport Economics 6, no. 2 (1979): 125-37.

6 Eric Pawson, The Early Industrial Revolution: Britain in the Eighteenth Century (London: Batsford, 1979).
} 
historians. One of them commended the book's arresting detail and its author's predisposition to take a microview, but (perhaps reflecting its intended audience), he found $E I R$ 'descriptive and visual rather than analytical and conceptual'. ${ }^{7}$

Half a world removed from Oxford, Eric largely abandoned work on the country of his birth after the publication of EIR, although Peter Perry's long-standing and continuing commitment to things British demonstrated the feasibility of staying this course. International relocations pose challenges aplenty, but those entailed in developing historical research expertise in a radically different setting are at least their equal. Still, Eric decided that making a life in a new land meant making that place the focus of his work. It took time to gain traction in this direction, and in the end Eric's New Zealand research trajectory came to resemble the complex braided rivers of the Canterbury Plains rather than the confined and steady streams of the temperate English countryside.

Bursting forth in sudden spates of publication, carving new channels, and responding to shifting local circumstances, Pawson's oeuvre is almost impossible to summarise succinctly. Its emphases shifted over time and were never tightly constrained. In very broad terms, historical geographical contributions were predominant through the 1990s, when they ceded ground, gradually, to work more accurately characterised as environmental history, and a string of publications on teaching and learning. But such classifications are more procrustean than most, even if one adds such portmanteau categories as 'current' and 'other' to accommodate a score and more of otherwise-difficult-to-place articles. Shifts were neither complete nor dramatic. The border between Eric's historical-geographical and environmental-historical contributions was permeable to the point of erasure in the years after 2000, and there was a deal of cross-pollination among the various strands of his scholarly writing. ${ }^{8}$ Eric's early established commitment to exploring significant problems is threaded through much of his work, early and late. ${ }^{9}$ So too is his inclination to connect his inquiries to current methodologies and debates. ${ }^{10}$ Nor did he shy away

7 S. D. Chapman, 'Review of Pawson, The Early Industrial Revolution', Journal of Economic History 39, no. 4 (1979): 1031, doi.org/10.1017/S0022050700098806.

8 For example, Eric Pawson and Peter Holland, 'People, environment and landscape since the 1840s', in The Natural History of Canterbury, 3rd ed., ed. M. Winterbourne et al. (Christchurch: Canterbury University Press, 2008), 37-64 and Eric Pawson, 'What Sort of Geographical Education for the Anthropocene?', Geographical Research 53, no. 3 (2015): 306-12, doi.org/10.1111/1745-5871.12122.

9 For example, Eric Pawson and G. Scott, 'The regional consequences of economic restructuring: The West Coast, New Zealand (1984-1991)', Journal of Rural Studies 8, no. 4 (1992): 373-86, doi.org/10.1016/07430167(92)90051-7.

10 For example, David Conradson and Eric Pawson, 'New cultural economies of marginality: Revisiting the West Coast, South Island, New Zealand', Journal of Rural Studies 25, no. 1 (2009): 77-86, doi.org/10.1016/j. jrurstud.2008.06.002; Eric Pawson, 'Postcolonial New Zealand?', in Cultural Geographies, ed. K. Anderson and F. Gale (South Melbourne, Vic.: Addison Wesley, 1999), 25-50; Eric Pawson and Garth Cant, 'Land rights in historical and contemporary context', Applied Geography 12, no. 2 (1992): 95-108, doi.org/10.1016/01436228(92)90001-4. 
from questions of social relevance. ${ }^{11}$ And the earthquakes that shook Canterbury in 2010 and 2011 perhaps inevitably reoriented Eric's teaching and broader societal concerns towards questions of resilience and community engagement. ${ }^{12}$

An important early strand of Pawson's Antipodean work, rooted in his doctoral interests, focused on information circulation and time standardisation in New Zealand. The first fruits of this appeared in 1982, in a groundbreaking article coauthored with Neil Quigley, who completed an important MA thesis under Eric's supervision in $1980 .{ }^{13}$ Combining detailed archival work in local sources with a firm grasp of the relevant international literature, the article illuminated the impact of the telegraph on the development of Canterbury, systemised and generalised its findings in a schematic model of 'information circulation and urban growth', and extended and clarified James Vance's influential account of the development of colonial urban networks. ${ }^{14}$ A decade later, two articles on local and standard time and time-space convergence in New Zealand further developed this line of inquiry, demonstrating how a 'new information technology', the telegraph, affected 'the conduct of government, business and the press'. ${ }^{15}$ In the 1980s, Pawson also developed a familiarity with, a fascination for, and a fast-increasing grasp of the intricacies of, the landscapes of Canterbury and the rest of the country. This mirrored a time-honoured interest of New Zealand historical geographers. Since the 1940s, Kenneth Cumberland, A. H. Clark, and Murray McCaskill, all sometime members of the Canterbury department, as well as Ray Hargreaves at Otago, had written extensively on the creation of New Zealand's human landscapes, and the landscape-scale work of geomorphologists such as Charles Cotton (in Wellington)

11 For example, suggesting that New Zealand educational institutions were 'schools for cultural reproduction', and urging colleagues to be more critical of New Zealand institutions' open endorsement of 'the interests of capital, patriarchy and Pakeha', in a review article considering recent work on the Treaty of Waitangi: Eric Pawson, '1990 and the Treaty', New Zealand Geographer 47, no. 1 (1991): 32-5; and reflecting on the implications of the neoliberalisation of New Zealand universities in Julie Cupples and Eric Pawson, 'Giving an account of oneself: The PBRF and the neoliberal university', New Zealand Geographer 68, no. 1 (2012): 14-23.

12 Eric Pawson, 'Environmental hazards and natural disasters', New Zealand Geographer 67, no. 3 (2011): 143-7, doi.org/10.1111/j.1745-7939.2011.01207.x; M. R. Dionisio and Eric Pawson, 'Building resilience through post-disaster community projects: Responses to the 2010 and 2011 Christchurch earthquakes and 2011 Töhoku tsunami', Australasian Journal of Disaster and Trauma Studies 20, no. 2 (2016): 107-16.

13 Eric Pawson and Neil C. Quigley, 'The Circulation of Information and Frontier Development: Canterbury 1850-1890', New Zealand Geographer 38, no. 2 (1982): 65-76, doi.org/10.1111/j.1745-7939.1982.tb00995.x; Neil C. Quigley, 'Patterns and Processes in the Development of Frontier Canterbury, 1850-1890' (MA diss., University of Canterbury, 1980).

14 J. E. Vance, The Merchant's World: The Geography of Wholesaling (Englewood Cliffs, NJ: Prentice Hall, 1970). 15 Eric Pawson, 'Local times and standard time in New Zealand', Journal of Historical Geography 18, no. 3 (1992): 278-87, doi.org/10.1016/0305-7488(92)90204-M, and Eric Pawson, 'Time-Space Convergence in New Zealand: 1850s to 1990s', New Zealand Journal of Geography 94, no. 1 (1992): 14-19, doi.org/10.1111/j.0028-8292.1992. tb00433.x. Eric Pawson and Tony Hoare, 'Regional isolation, railways and politics: Nelson, New Zealand', Journal of Transport History 10, no. 1 (1989): 22-40, doi.org/10.1177/002252668901000103, is by comparison a straightforward narrative treatment of political debates over the relative landward inaccessibility of the city of Nelson. 
and Bill Brockie (in Dunedin) both enticed and assisted such inquiries. ${ }^{16}$ Those lucky enough to have travelled through parts of New Zealand with Eric (in ones or twos, or in larger groups on the meticulously planned field trips that he is so adept at organising) have been the most direct beneficiaries of his astute interpretative eye and an increasingly compendious knowledge of the New Zealand scene.

In the end, though, Eric published less than he knew on the historical geography of landscape change in New Zealand. ${ }^{17}$ As the country was radically remade, after 1984, by government policies that hastened economic deregulation and privatisation, Eric was drawn into a major collaborative effort-an authoritative and comprehensive review of the effects of the restructuring-involving 50 colleagues. As one of three editors of Changing Places, published in 1992, he demonstrated his impressive capacity to bring major joint projects to insightful and coherent conclusion. ${ }^{18}$ For all the attention turned to contemporary challenges, however, these years formed a robust foundation for Eric's subsequent contributions to the New Zealand Historical Atlas (NZHA) project and the emergence of environmental history as a vigorous and respected subfield of New Zealand scholarship.

Appointed to chair the advisory board of the NZHA, Eric was, for seven years, an influential hand on the helm of this great national project that included 100 largeformat, full-colour plates embracing a range of cartographic expression to create maps 'about people for people. ${ }^{19}$ In addition to offering intellectual leadership and an inclusive vision for the atlas, Eric served as a contributing editor and authored four plates, elaborating and giving impressive cartographic expression to his earlier

16 Pawson has written on Cumberland: Eric Pawson, 'Kenneth Cumberland (1913-2011)', in Geographers Biobibliographical Studies, 31, ed. Hayden Lorimer and C. W. J. Withers (London: Bloomsbury, 2012): 137-60 and Eric Pawson, 'Creating public spaces for geography in New Zealand: Towards an assessment of the contributions of Kenneth Cumberland', New Zealand Geographer 67, no. 2 (2011): 102-15, doi.org/10.1111/ j.1745-7939.2011.01203.x; for others, see A. H. Clark, The Invasion of New Zealand by People, Plants and Animals (New Brunswick, NJ: Rutgers University Press, 1949); A. S. Fraser, 'Murray McCaskill, 1926-1999', Australian Geographical Studies 37, no. 3 (1999): 343-6, doi.org/10.1111/1467-8470.00093; Geoff Kearsley and B. B. Fitzharris, eds., Southern landscapes: Essays in honour of Bill Brockie and Ray Hargreaves (Dunedin: Department of Geography, Otago University, 1990); G. R. Stevens, 'Cotton, Charles Andrew, 1885-1970', Dictionary of New Zealand Biography, 4 (1998) www.teara.govt.nz/en/biographies/4c38/cotton-charles-andrew.

17 But among other items below, see Paul Cloke and Eric Pawson, 'Memorial trees and treescape memories', Environment and Planning D: Society and Space 26, no. 1 (2008): 107-22, doi.org/10.1068/d79j; Eric Pawson and Peter Holland, 'Lowland Canterbury landscapes in the making', New Zealand Geographer, 61, no. 2 (2005), 167-75, doi.org/10.1111/j.1745-7939.2005.00020.x; Eric Pawson, 'The memorial oaks of north Otago: a commemorative landscape', in Glimpses of a Gaian World, ed. G. Kearsley and B. B. Fitzharris (Dunedin: University of Otago, 2004), 115-31; Eric Pawson, 'Monuments, Memorials and Cemeteries: Icons in the Landscape', New Zealand Journal of Geography 92, no. 1 (1991): 26-7, doi.org/10.1111/j.0028-8292.1991.tb00302.x.

18 Steve Britton, Richard Le Heron, and Eric Pawson, eds., Changing Places in New Zealand: A geography of restructuring (Christchurch: New Zealand Geographical Society, 1992); and the second version of this important statement: Richard Le Heron and Eric Pawson, eds., Changing Places: New Zealand in the Nineties (Auckland: Longman Paul, 1996).

19 Malcolm McKinnon, ed., Bateman New Zealand Historical Atlas—ko papatuanuku e takoto nei (Auckland: David Bateman in association with the Historical Branch, Department of Internal Affairs, 1997); Eric Pawson, 'The New Zealand Historical Atlas', Journal of Historical Geography 23, no. 4 (1997): 496-9, doi.org/10.1006/ jhge.1997.0065. 
work with Quigley in 'Space Transformed'; detailing coal mining on the west coast of the South Island; exploring urban form in Christchurch; and treating fire, flood, and earthquake hazards between the wars. ${ }^{20}$ Credit for the finished atlas, described as an 'authoritative, wide-ranging, beautiful, exciting and accessible gateway to New Zealand', is due many individuals, but Eric's people—and project—management skills were integral to the work's spectacular completion. From the labours of the atlas, Eric moved into a sustained and productive collaboration with Tom Brooking that put New Zealand environmental history on the international map, and about which Brooking says more in this issue. The rigorously conceived and tightly edited Environmental Histories of New Zealand appeared in 2002. Bringing together 21 contributors from agricultural science, anthropology, archaeology, ecology, geography, history, and law, it was, in the words of one newspaper reviewer, sufficiently accessible to be welcomed by 'farmers, environmentalists, and government personnel at local, regional and national levels', and would help, in her view, to "counteract the "amnesia" we have about the environmental changes we have effected'. The 'sweep ... curiosity and ... ambition' of this volume, observed the American environmental historian Richard White in a preface, is unmatched 'for any other country in the world'. ${ }^{21}$ A decade later, Environmental Histories formed the basis of Making a New Land, a thoroughly revised and updated collection incorporating a great deal of new research and bringing postcolonial perspectives to bear on the story of New Zealand. ${ }^{22}$

Much of the new scholarship incorporated in Making a New Land emerged from another exemplary Brooking-Pawson collaboration: the 'Empires of Grass' project supported by the Marsden Fund, which yielded Seeds of Empire in 2011. ${ }^{23}$ This book, a team project involving young scholars alongside more established practitioners, traces the pastoral transformation of New Zealand and explores the implications of farm intensification in the late nineteenth and early twentieth centuries. Among recurrent themes in this account of the struggles and pitfalls of colonial development are: the intersections of politics, imperialism, and the environment; the mobility of ideas about farming; the increasing influence of scientific expertise in shaping the land; and the biotic flows (of everything from guano to grass seed) that gave

20 Plates 52, 63, 95 (with Russell Kirkpatrick) and 87 in McKinnon, ed., Bateman New Zealand Historical Atlas.

21 Eric Pawson and Tom Brooking, eds., Environmental Histories of New Zealand (Melbourne: Oxford University Press, 2002); Philippa Jamieson, 'Review of Eric Pawson and Tom Brooking eds: Environmental Histories of New Zealand', New Zealand Herald, 12 September 2002.

22 Eric Pawson and Tom Brooking, eds., Making a New Land: Environmental Histories of New Zealand (Dunedin: Otago University Press, 2013), 158-73.

23 Tom Brooking and Eric Pawson, Seeds of Empire: The Environmental Transformation of New Zealand (London: I. B. Tauris, 2011). 
material form to the landscape. ${ }^{24}$ In the end, Seeds is a detailed, quietly revisionist, work demonstrating that there was nothing inevitable about New Zealand's transformation into a grassland/grazing empire and leaving no doubt that the choice exacted an environmental price.

In the conclusion to Making a New Land, Eric makes an argument for the importance of geographical and other disciplinary perspectives to the development of an environmental history that is more than 'history with nature added in', and points to the importance of developing a field that is broadly relevant. Environmental history, he insists, needs 'to develop an edge ... [and] frame its stories in ways that engage not only those interested in the past, but also those whose role it is to analyse and to manage environmental behaviour now and in the future' ${ }^{25}$

With these thoughts in mind, let me draw this too-brief vignette to a somewhat personal, somewhat metaphorical conclusion. One strand of Eric's work has explored the meanings given to mountains. ${ }^{26}$ These contributions, and others on the environmental history of New Zealand, chart a remarkable journey from the analytical and scientific geography that inspired his first work. Such analyses typically tended to treat the face of the earth as a featureless plain, as space rather than as a complex of places shaped by nature and human hands and invested with human meaning. Looking back over 40 years, it is clear that Eric himself has made meaning, and greatly enhanced understanding, of the plains and cities and towns, the landscapes, and the people, as well as the mountains of his adopted home.

Over the years I have talked, tripped, tramped, and travelled-using various forms of transport (mostly economical) — with Eric. One of the most well-beloved of such journeys was in the Netherlands, when he, Tom Brooking, Vaughan Wood, my wife Barbara, and I made a side trip from the European Society for Environmental History meetings of 2007, to visit the Hortus Botanicus in Leiden, one of the oldest botanic gardens in the world. There are photographs of the occasion-only one

24 See also Eric Pawson, 'Plants, mobilities and landscapes: Environmental histories of botanical exchange', Geography Compass 2, no. 5 (2008): 1464-77, doi.org/10.1111/j.1749-8198.2008.00153.x. The 'Empires of Grass' project led Pawson into a new Marsden-funded project on biological economies. For an early indication of this development, see Hugh Campbell et al., 'From agricultural science to "biological economies"?' New Zealand Journal of Agricultural Research 52, no. 1 (2009): 91-7, doi.org/10.1080/00288230909510492, and the later report N. Lewis et al., 'Assembling biological economies: Region-shaping initiatives in making and retaining value', New Zealand Geographer 69, no. 3 (2013): 180-96, doi.org/10.1111/nzg.12031.

25 Pawson and Brooking, eds., Making a New Land.

26 See Eric Pawson, 'The meanings of mountains', in Environmental Histories, ed. Pawson and Brooking, 136-50; Eric Pawson, “"Tipped with Alpine glow”? Mountains in the New Zealand imagination', Australian Canadian Studies 18, nos 1-2 (2000): 73-86; Eric Pawson and H.-R. Egli, 'History and (re)discovery of the European and New Zealand Alps until 1900', Mountain Research and Development 21, no. 4 (2001): 350-8, doi.org/10.1659/02764741(2001)021[0350:HARDOT]2.0.CO;2; and M. Johnston and Eric Pawson, 'Challenge and danger in the development of mountain recreation in New Zealand, 1890-1940', Journal of Historical Geography 20, no. 2 (1994):175-86, doi.org/10.1006/jhge.1994.1014. 
of which I am bold enough to reproduce here. It speaks volumes. This trip, like so many others with Eric, was full of environmental-historical-geographical talk and insight, but it was also, as usual, fun. It was Eric who suggested that we hire a boat and row the ancient canals. And here he is, doing just that while providing an allegorical summary of his career. He is, of course, looking backward, at where we have been -as rowers and historians must-but he is also moving forward purposefully, powered - I like to think - by the twin oars of historical geography and environmental history, to engage what lies ahead.

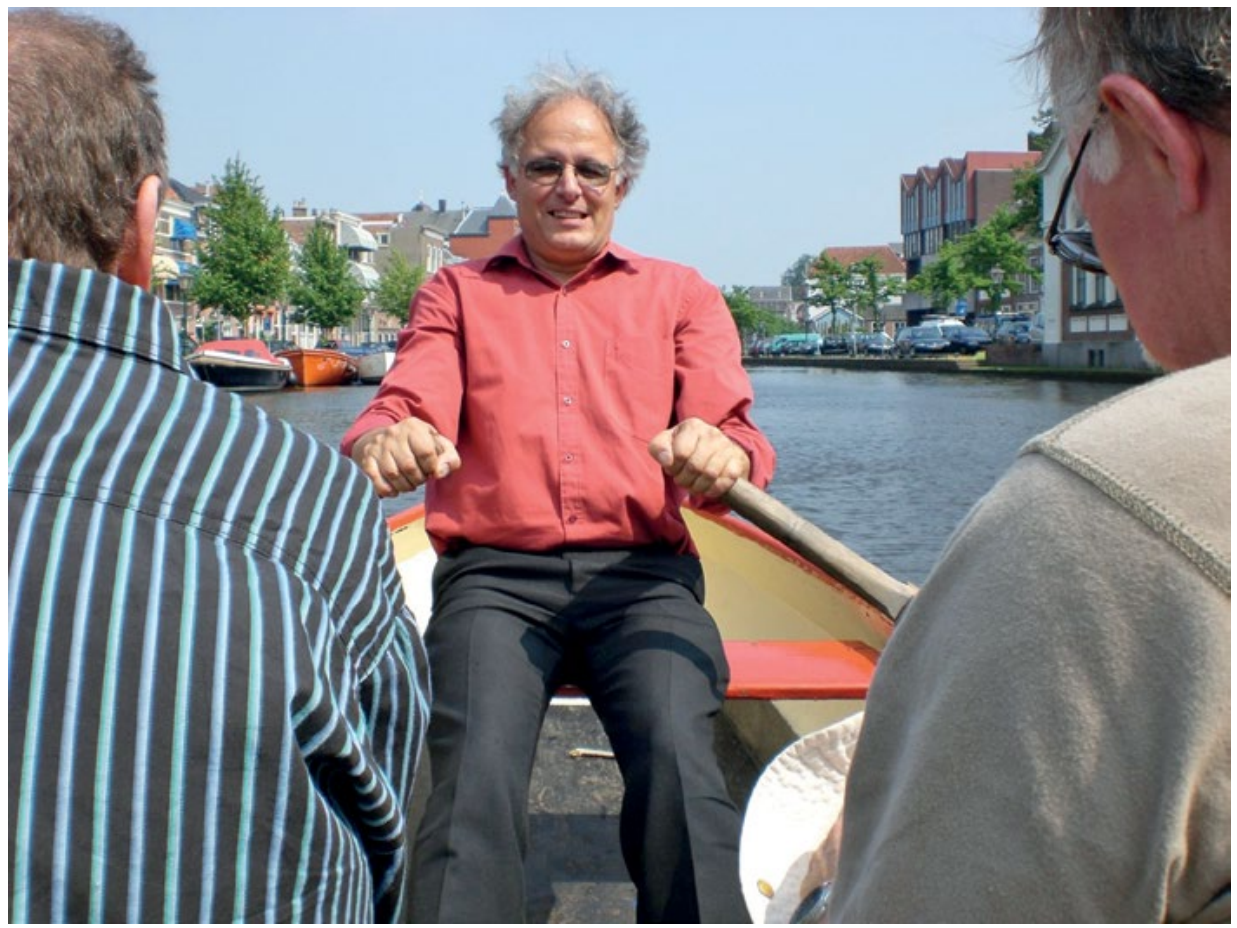

Figure 1: Eric Pawson rowing Leiden's canals, 2007.

Source: Graeme Wynn. 
This text is taken from International Review of Environmental History, Volume 3, Issue 1, 2017, edited by James Beattie, published 2017 by ANU Press, The Australian National University, Canberra, Australia. 